\title{
Complete genome sequence of Pseudomonas fluorescens strain PICF7, an indigenous root endophyte from olive (Olea europaea L.) and effective biocontrol agent against Verticillium dahliae
}

\author{
Pedro Manuel Martínez-García ${ }^{1,4}$, David Ruano-Rosa², Elisabetta Schilirò2, Pilar Prieto ${ }^{3}$, Cayo Ramos ${ }^{1}$, \\ Pablo Rodríguez-Palenzuela ${ }^{4 *}$ and Jesús Mercado-Blanco ${ }^{2}$
}

\begin{abstract}
Pseudomonas fluorescens strain PICF7 is a native endophyte of olive roots. Previous studies have shown this motile, Gram-negative, non-sporulating bacterium is an effective biocontrol agent against the soil-borne fungus Verticillium dahliae, the causal agent of one of the most devastating diseases for olive (Olea europaea L.) cultivation. Here, we announce and describe the complete genome sequence of Pseudomonas fluorescens strain PICF7 consisting of a circular chromosome of 6,136,735 bp that encodes 5,567 protein-coding genes and 88 RNA-only encoding genes. Genome analysis revealed genes predicting factors such as secretion systems, siderophores, detoxifying compounds or volatile components. Further analysis of the genome sequence of PICF7 will help in gaining insights into biocontrol and endophytism.
\end{abstract}

Keywords: Pseudomonas fluorescens, Olive, Endophyte, Biocontrol, Verticillium wilt, Siderophores, Detoxification systems

\section{Introduction}

Pseudomonas fluorescens PICF7 is a native colonizer of olive (Olea europaea L.) roots and an in vitro antagonist of the soil-borne fungal phytopathogen Verticillium dahliae Kleb. [1], the causal agent of Verticillium wilts in a large number of plant species [2]. This strain has been demonstrated to be an effective BCA against Verticillium wilt of olive [1,3], one of the most important biotic constraints for olive cultivation [4]. Moreover, strain PICF7 is able to display an endophytic lifestyle within olive root tissues under different experimental conditions $[3,5,6]$ and induces a broad range of defence responses at both local (roots) and systemic (above-ground organs) level, as well as to activate diverse transcription factors known to be involved in systemic defence responses [7,8]. Accordingly, a recent

\footnotetext{
*Correspondence: pablo.rpalenzuela@upm.es

${ }^{4}$ Centro de Biotecnología y Genómica de Plantas (UPM- INIA), Campus de Montegancedo 28223, Pozuelo de Alarcón, Madrid, Spain

Full list of author information is available at the end of the article
}

study has shown the ability of PICF7 to influence the establishment of the pathogen Pseudomonas savastanoi pv. savastanoi in olive stems and to affect the normal development of olive knots [9], its associated disease [10].

In this report, we summarize the complete genome sequence and annotation of PICF7. We also describe its genomic properties, highlighting genes encoding plantassociated factors, colonization abilities and well-known bacterial biocontrol traits. The genome sequencing of PICF7 and its comparison with related published genomes will provide a framework for further functional studies of its rhizosphere competence, biocontrol effectiveness and endophytic lifestyle.

\section{Classification and features}

P. fluorescens PICF7 is a motile, Gram-negative, nonsporulating rod in the order Pseudomonadales of the class Gammaproteobacteria. Rod-shaped cells are approximately $0.5 \mu \mathrm{m}$ in width and 2.0-2.5 $\mu \mathrm{m}$ in length (Figure 1 Left 


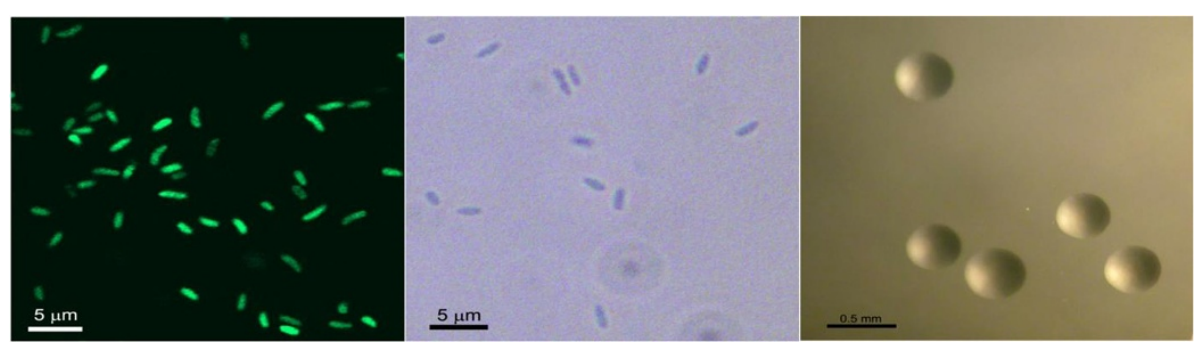

Figure 1 Image of $P$. fluorescens PICF7 cells using confocal laser scanning (Left) and phase-contrast (Centre) microscopy (CLSM and $\mathrm{PCM}$, respectively) and the appearance of colony morphology after $24 \mathrm{~h}$ growing on $\mathrm{KB}$ agar medium at $28^{\circ} \mathrm{C}$ (Right). CLSM image was obtained using a PICF7 derivative carrying a plasmid with an enhanced green fluorescent protein (EGFP) [5].

and Centre). The strain is moderately fast-growing, forming $2 \mathrm{~mm}$ colonies within 2-3 days at $28^{\circ} \mathrm{C}$. Colonies formed on King's B (KB) [11] agar plates are yellow-green opaque, domed and moderately mucoid with smooth margins (Figure 1 Right).

PICF7 was isolated from the roots of healthy nurseryproduced olive plants cv. Picual in Córdoba province (Southern Spain) [1]. It grows in complex media such as LB [12] or $\mathrm{KB}$, as well as in minimal media such as Standard Succinate Medium (SSM; pH 7.0) [13]. Even though the optimal growth temperature is $28^{\circ} \mathrm{C}$, PICF7 can also slightly replicate at $5^{\circ} \mathrm{C}$ in liquid $\mathrm{LB}$ and $\mathrm{KB}$. However, growth at $37^{\circ} \mathrm{C}$ was not observed in these culturing media after $24 \mathrm{~h}$. The bacterium is an efficient colonizer of the olive rhizosphere [1] and displays an endophytic lifestyle $[3,5,6]$. It does not cause any deleterious effect on its original host (olive) $[1,5,9]$. Strain PICF7 has natural resistance to kanamycin $(50 \mathrm{mg} / \mathrm{L})$ and nalidixic acid $(25 \mathrm{mg} / \mathrm{L})$, and it is possible to develop spontaneous rifampicin-resistant mutants [1].

Minimun Information about the Genome Sequence (MIGS) of P. fluorescens PICF7 is summarized in Table 1, and its phylogenetic position is shown in Figure 2.

\section{Genome sequencing and annotation}

\section{Genome project history}

P. fluorescens strain PICF7 was selected for sequencing due to its ability to exert biocontrol against Verticillium wilt of olive $[1,3]$ and to develop an endophytic lifestyle within olive root tissues $[5,6]$. The genome project is deposited in the Genomes OnLine Database [31] and the NCBI BioProject database. The finished genome sequence is in GenBank. A summary of the project information is shown in Table 2.

\section{Growth conditions and DNA isolation}

P. fluorescens strain PICF7 was grown in $50 \mathrm{ml}$ of LB medium and incubated for $16 \mathrm{~h}$ at $28^{\circ} \mathrm{C}$. After this period of time, the OD600 of the culture was 1.2. Serial dilutions from this culture and plating on LB plates yielded $2.8 \times 10^{8} \mathrm{CFU} / \mathrm{mL}$ of a pure bacterial culture (colonies showed uniform morphology and kanamycin resistance). The culture was divided into two $25-\mathrm{ml}$ aliquots and total genomic DNA was extracted using the 'Jet-Flex genomic DNA purification' kit (Genomed $\mathrm{GmbH}$, Löhne, Germany), according to the manufacturer's indications. DNA samples were further purified by extraction with phenol:chloroform and precipitation with ethanol. DNA quality and quantity were checked by agarose gel electrophoresis, spectrophotometry using a ND-1000 spectrophotometer (NanoDrop Technologies, Wilmington, DE), and digestion with different restriction enzymes. Two DNA aliquots $(0.6 \mu \mathrm{g} / \mu \mathrm{L}, \sim 20 \mu \mathrm{g}$ each $)$ were sent in a dry ice container to the sequencing service.

\section{Genome sequencing and assembly}

The genome of PICF7 was sequenced at the Beijing Genomics Institute (BGI) using Solexa paired-end sequencing. Draft assemblies were based on 3,482,351 reads with a length of $500 \mathrm{bp}$ resulting in 1,200 Mb, $2,456,221$ reads with a length of $2,000 \mathrm{bp}$ resulting in $1,209 \mathrm{Mb}$ and 1,924,515 reads with a length of $6,000 \mathrm{bp}$ resulting in 1,309 $\mathrm{Mb}$. The SOAPdenovo 1.05 software package [32-34] developed by BGI was used for sequence assembly and quality assessment.

\section{Genome annotation}

Automatic annotation was performed using the NCBI Prokaryotic Genome Annotation Pipeline. Identification of known type III effectors effectors was conducted by BLASTP searches of the effectors described in http:// pseudomonas-syringae.org/ against the proteome of PICF7. Functional annotation was performed by aligning the predicted protein sequences against the COG PSSM of the CDD using RPS-BLAST. Hits with an E-value $<=0.001$ were first retained. Then, only the best hit was selected for each protein. Signal peptides and transmembrane helices were predicted using SignalP $[35,36]$ and TMHMM $[37,38]$, respectively. 
Table 1 Classification and the general features of Pseudomonas fluorescens PICF7 according to the MIGS recommendations [14]

\begin{tabular}{|c|c|c|c|}
\hline MIGS ID & Property & Term & Evidence code $^{\mathrm{a}}$ \\
\hline & & Domain Bacteria & TAS [15] \\
\hline & & Phylum Proteobacteria & TAS [16] \\
\hline & & Class Gammaproteobacteria & $\operatorname{TAS}[17,18]$ \\
\hline & Classification & Order Pseudomonadales & $\operatorname{TAS}[19,20]$ \\
\hline & & Family Pseudomonadaceae & TAS $[21,22]$ \\
\hline & & Genus Pseudomonas & TAS [21-25] \\
\hline & & Species Pseudomonas fluorescens & TAS $[26,27]$ \\
\hline & & Strain PICF7 & TAS $[1,5]$ \\
\hline & Gram stain & Negative & TAS [26] \\
\hline & Cell shape & Rod-shaped & TAS [26] \\
\hline & Motility & Motile & TAS [26] \\
\hline & Sporulation & None & NAS \\
\hline & Temperature range & Mesophilic & IDA \\
\hline & Optimum temperature & $28^{\circ} \mathrm{C}$ & IDA \\
\hline \multirow[t]{3}{*}{ MIGS-22 } & Oxygen & Aerobic & IDA, TAS [26] \\
\hline & Carbon source & Heterotrophic & IDA, TAS [26] \\
\hline & Energy metabolism & Chemoorganotrophic & NAS \\
\hline MIGS-6 & Habitat & Soil, olive root-associated & $\operatorname{TAS}[1,5]$ \\
\hline MIGS-6.3 & Salinity & $\mathrm{NaCl} 1-4 \%$ & IDA \\
\hline MIGS-10 & Extrachromosomal elements & None & IDA \\
\hline MIGS-11 & Estimated size & $6.14 \mathrm{Mb}$ & IDA \\
\hline MIGS-15 & Biotic relationship & Rhizospheric, root endophytic & $\operatorname{TAS}[1,3,5,6]$ \\
\hline \multirow[t]{5}{*}{ MIGS-14 } & Pathogenicity & Non-pathogenic & $\operatorname{TAS}[1,3,5]$ \\
\hline & Host & Olea europaea & TAS [1] \\
\hline & Host taxa ID & 4146 & \\
\hline & Isolation source & Root & TAS [1] \\
\hline & Biosafety level & 1 & NAS \\
\hline MIGS-4 & Geographic location & Córdoba, Spain & TAS [1] \\
\hline MIGS-5 & Sample collection time & 1998 & TAS [1] \\
\hline MIGS-4.1 & Latitude & $37^{\circ} 41^{\prime} 28^{\prime \prime} \mathrm{N}$ & NAS \\
\hline MIGS-4.2 & Longitude & $4^{\circ} 28^{\prime} 58^{\prime \prime} \mathrm{W}$ & NAS \\
\hline MIGS-4.4 & Altitude & 230 m.a.s.l & NAS \\
\hline
\end{tabular}

${ }^{a}$ Evidence codes - IDA: Inferred from Direct Assay (first time in publication); TAS: Traceable Author Statement (a direct report exists in the literature); NAS: Non-traceable Author Statement (not directly observed for the living, isolated sample, but based on a generally accepted property of the species, or anecdotal evidence). These evidence codes are from the Gene Ontology project [28].

\section{Genome properties}

The genome of PICF7 is composed of one circular chromosome of 6,136,735 bp with an average GC content of $60.4 \%$ (Table 3 and Figure 3), which is similar to that of other P. fluorescens strains. Among the 5,655 predicted genes, 5,567 were identified as protein coding genes. Of the last, $4,573(82.1 \%)$ were assigned a putative function, while the other 994 (17.9\%) were designated as hypothetical proteins. The classification of CDSs into functional categories according to the COG (Clusters of Orthologous Groups) [39,40] database is summarized in Table 4.

\section{Insights from the genome sequence}

The genome contains a complete canonical type III secretion system and two known effector proteins, namely, 


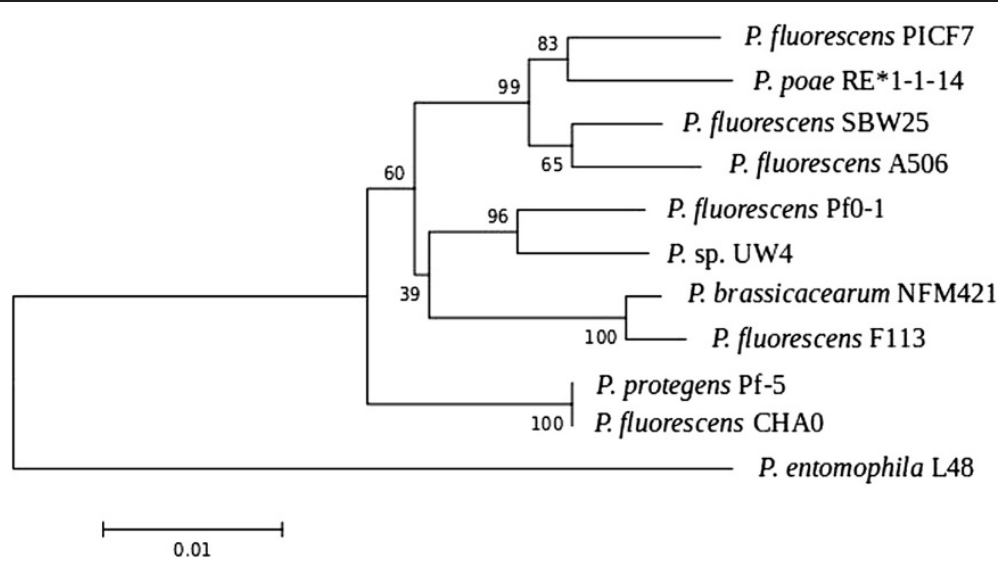

Figure 2 Phylogenetic tree highlighting the position of $P$. fluorescens strain PICF7 relative to its closest Pseudomonas strains for which complete genomes are available. P. entomophila strain $L 48$ was used as an outgroup. For the construction of the tree, five protein-coding house-keeping genes were first aligned, namely: $\operatorname{argF}$, atpA, nusA, pyrH and rpoH. Then, Maximum Likelihood method based on the JTT (Jones-Taylor-Thornton) matrix-based model [29] was used. The percentage of trees in which the associated taxa clustered in the bootstrap test (1000 replicates) is shown next to the branches [30].

AvrE1 and HopB1. In addition, two complete type VI secretion system (T6SS) clusters were identified. T6SS has been described to promote antibacterial activity against a wide range of competitor bacteria [41]. PICF7 genome also encodes gene clusters for the synthesis of the siderophores pyochelin and pyoverdine and the hemophore HasAp. A repertoire of cell adhesion proteins has been also identified, including two filamentous hemagglutinin proteins and several fimbrial proteins clustered together with a number of pilus assembly proteins. Notably, two genes have been found to show high similarity with attC and attG genes from Agrobacterium, whose mutation leads

Table 2 Project information

\begin{tabular}{lll}
\hline MIGS ID & Property & Term \\
\hline MIGS-31 & Finishing quality & Finished \\
MIGS-28 & Libraries used & $\begin{array}{l}\text { Three libraries of } 500 \mathrm{bp}, 2,000 \mathrm{bp} \\
\text { and 6,000 bp, respectively }\end{array}$ \\
MIGS-29 & Sequencing platforms & Solexa \\
MIGS-31.2 & Fold coverage & $200 x$ \\
MIGS-30 & Assemblers & SOAPdenovo 1.05 \\
MIGS-32 & Gene calling method & NCBI Prokaryotic Genome \\
& & Annotation Pipeline \\
& Locus Tag & PFLUOLIPICF7 \\
& Genbank ID & CP005975 \\
& GenBank Date of Release & May 31, 2017 \\
& GOLD ID & Gi0079402 \\
& BIOPROJECT & PRJNA203247 \\
& NCBI taxon ID & 1334632 \\
& Project relevance & Plant-bacteria interaction, \\
& & Model for endophytic lifestyle, \\
& Agricultural, Environmental
\end{tabular}

to lack of attachment on tomato, carrot, and Bryophyllum daigremontiana [42].

It is worth mentioning the presence of genome components presumably involved in the synthesis of detoxifying compounds. Such is the case of two clusters containing genes for copper resistance and for production of a cbb (3)-type cytochrome C oxidase, respectively. An ortholog of the gene that codes for Dps, a ferritin-like protein reported to protect plant-associated bacteria against oxidative stress [43], has also been found. Additional identified traits involved in detoxification are orthologs of catalase KatB and hydroperoxidase KatG, which detoxify plant-

Table 3 Genome statistics

\begin{tabular}{lrr}
\hline Attribute & \multicolumn{2}{c}{ Genome (total) } \\
\cline { 2 - 3 } & Value & \% of total \\
\hline Genome size (bp) & $6,136,735$ & 100 \\
DNA coding region (bp) & $5,439,499$ & 88.6 \\
DNA G+C content (bp) & $3,706,588$ & 60.4 \\
DNA scaffolds & 1 & - \\
Total genes & 5,655 & 100 \\
Protein-coding genes & 5,567 & 98.4 \\
RNA genes & 88 & 1.6 \\
Pseudo genes & 30 & 0.8 \\
Genes in internal clusters & $\mathrm{NA}$ & - \\
Protein-coding genes with function prediction & 4,573 & 82.1 \\
Protein-coding genes assigned to COGs & 4,581 & 82.3 \\
Proteins with signal peptides & 644 & 11.6 \\
Proteins with transmembrane helices & 1,319 & 23.7 \\
CRISPR repeats & $\mathrm{NA}$ & - \\
\hline
\end{tabular}




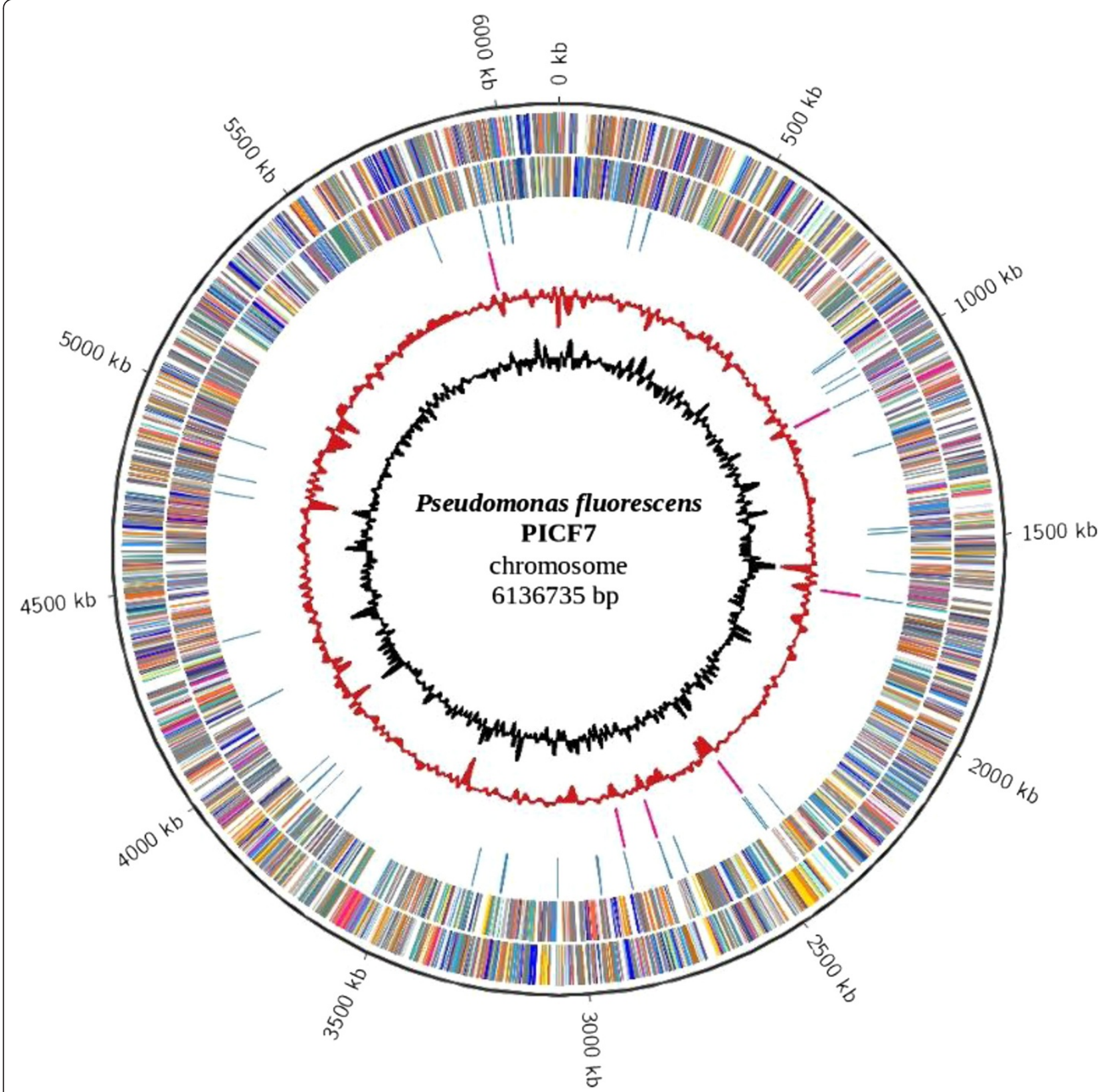

Figure 3 Graphical map of the chromosome. From outside to the centre: genes on forward strand (coloured by COG categories), genes on reverse strand (coloured by COG categories), RNA genes: tRNAs - blue, rRNAs - pink, G $+C$ in relation to the mean $\mathrm{G}+\mathrm{C}$ in $2 \mathrm{~kb}$ windows and trinucleotide distribution in $2 \mathrm{~kb}$ windows. The latter was defined as the $x 2$ statistic on the difference between the trinucleotide composition of $2 \mathrm{~kb}$ windows and that of the whole chromosome.

produced $\mathrm{H}_{2} \mathrm{O}_{2}$ [44], and a gene coding for a proline iminopeptidase, which has been shown to have dealanylating activity toward the antibiotic ascamycin [45]. A gene predicting a salycilic hydroxylase has been also identified in PICF7 genome. This gene could be involved in the degradation of the plant defence hormone salicylic acid, thus disrupting the systemic response against colonizing bacteria. In addition, all genes required for biosynthesis of the exopolysaccharide alginate [46] are present in a gene cluster.

Genes predicting volatile components are present in PICF7 genome as well. Volatile components have been shown to act as antibiotics and to induce plant growth $[47,48]$. An example is hydrogen cyanide $(\mathrm{HCN})$, an inorganic compound with antagonistic effects against soil microbes [49]. Orthologs of genes required for 
Table 4 Number of genes associated with general COG functional categories

\begin{tabular}{|c|c|c|c|}
\hline Code & Value & $\%$ of total ${ }^{\mathrm{a}}$ & Description \\
\hline J & 200 & 3.59 & Translation \\
\hline A & 1 & 0.02 & RNA processing and modification \\
\hline K & 501 & 9 & Transcription \\
\hline L & 156 & 2.8 & Replication, recombination and repair \\
\hline B & 5 & 0.09 & Chromatin structure and dynamics \\
\hline D & 41 & 0.74 & Cell cycle control, mitosis and meiosis \\
\hline Y & - & - & Nuclear structure \\
\hline V & 67 & 1.2 & Defense mechanisms \\
\hline $\mathrm{T}$ & 366 & 6.57 & Signal transduction mechanisms \\
\hline M & 267 & 4.8 & Cell wall/membrane biogenesis \\
\hline N & 162 & 2.9 & Cell motility \\
\hline Z & - & - & Cytoskeleton \\
\hline W & - & - & Extracellular structures \\
\hline$U$ & 153 & 2.75 & Intracellular trafficking and secretion \\
\hline $\mathrm{O}$ & 177 & 3.18 & $\begin{array}{l}\text { Posttranslational modification, protein } \\
\text { turnover, chaperones }\end{array}$ \\
\hline C & 280 & 5.03 & Energy production and conversion \\
\hline G & 307 & 5.51 & Carbohydrate transport and metabolism \\
\hline$E$ & 554 & 9.95 & Amino acid transport and metabolism \\
\hline $\mathrm{F}$ & 96 & 1.72 & Nucleotide transport and metabolism \\
\hline $\mathrm{H}$ & 196 & 3.52 & Coenzyme transport and metabolism \\
\hline I & 219 & 3.93 & Lipid transport and metabolism \\
\hline$P$ & 301 & 5.41 & Inorganic ion transport and metabolism \\
\hline Q & 151 & 2.71 & $\begin{array}{l}\text { Secondary metabolites biosynthesis, } \\
\text { transport and catabolism }\end{array}$ \\
\hline $\mathrm{R}$ & 592 & 10.63 & General function prediction only \\
\hline$S$ & 446 & 8.01 & Function unknown \\
\hline- & 986 & 17.7 & Not in COGs \\
\hline
\end{tabular}

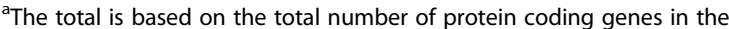
annotated genome.

the biosynthesis of other volatile components such as 2,3-butanediol and acetoin were also found. Further genome analysis revealed other factors presumably involved in the endophytic fitness of PICF7. Such is the case of enzymes like a cellulase and a phytase, as well as the gene coding for aminocyclopropane-1-carboxylate deaminase suggested to be key in the modulation of ethylene levels in plants by bacteria [50].

\section{Conclusions}

In this report we describe the complete genome sequence of Pseudomonas fluorescens strain PICF7, a "Pseudomonadales" in the order Gammaproteobacteria that was originally isolated from the roots of healthy nursery-produced olive plants cv. Picual in Córdoba province, Spain. This strain was selected for sequencing based on its ability to exert biocontrol against Verticillium wilt of olive and to develop an endophytic lifestyle within olive root tissues. Such properties likely have origins in a repertoire of genes including a putative T3SS, two putative T6SS, and several genes presumably implicated in siderophore production. It also has a collection of genes predicting adhesion proteins, detoxifying compounds, volatile components and enzymes such as a cellulase, aphytase and a deaminase. Further functional studies and comparative genomics with related isolates will provide insights into biocontrol and endophytism.

\section{Competing interests}

The authors declare that they have no competing interests.

\section{Authors' contributions}

JMB conceived and designed the experiments. DRR, ES and PP performed the experiments. PMMG performed the annotation and sequence homology searches. PMMG, CR, JMB and PRP wrote the manuscript. All authors commented on the manuscript before submission. All authors read and approved the final manuscript.

\section{Acknowledgements}

This Project was supported by grants P07-CVI-02624, P10-AGR-5797, P12-AGR-667 (Convocatoria Proyectos de Excelencia from Junta de Andalucía, Spain), co-funded by ERDF from EU, grant AGL2011-30343-CO2-01 from the MINECO (Spain), co-financed by FEDER, and the Campus de Excelencia Internacional Andalucía Tech. P. M. Martínez was supported by the Campus de Exelencia Internacional Andalucía Tech. The authors would like to thank Prof. Antonio de Vicente and Dr. Eva Arrebola for the logistics and shipment of DNA samples to BGI.

\section{Author details}

'Instituto de Hortofruticultura Subtropical y Mediterránea "La Mayora", Universidad de Málaga - Agencia Estatal Consejo Superior de Investigaciones Científicas (IHSM-UMA-CSIC), Área de Genética, Facultad de Ciencias, Málaga, Spain. ${ }^{2}$ Departmentos de Potección de Cultivos y, Campus 'Alameda del Obispo' s/n, Apartado 408414080 Córdoba, Spain. ${ }^{3}$ Departmentos de Mejora Genética Vegetal, Instituto de Agricultura Sostenible (CSIC), Campus 'Alameda del Obispo' s/n, Apartado 4084, 14080 Córdoba, Spain. ${ }^{4}$ Centro de Biotecnología y Genómica de Plantas (UPM- INIA), Campus de Montegancedo 28223, Pozuelo de Alarcón, Madrid, Spain

Received: 31 July 2014 Accepted: 25 November 2014 Published: 6 February 2015

\section{References}

1. Mercado-Blanco J, Rodríguez-Jurado D, Hervas A, Jiménez-Díaz RM. Suppression of Verticillium wilt in olive planting stocks by root-associated fluorescent Pseudomonas spp. Biol Control. 2004 30:474-86.

2. Pegg GF, Brady BL. Verticillium wilts. Wallingford: CAB International. 2002

3. Prieto $P$, Navarro-Raya C, Valverde-Corredor A, Amyotte SG, Dobinson KF, Mercado-Blanco J. Colonization process of olive tissues by Verticillium dahliae and its in planta interaction with the biocontrol root endophyte Pseudomonas fluorescens PICF7. Microb Biotechnol. 2009; 2:499-511.

4. López-Escudero FJ, Mercado-Blanco J. Verticillium wilt of olive: a case study to implement an integrated strategy to control a soil-borne pathogen. Plant Soil. 2011; 344:1-50.

5. Prieto P, Mercado-Blanco J. Endophytic colonization of olive roots by the biocontrol strain Pseudomonas fluorescens PICF7. FEMS Microbiol Ecol. 2008; 64:297-306.

6. Prieto $P$, Schilirò E, Maldonado-González M, Valderrama R, Barroso-Albarracín $J B$, Mercado-Blanco J. Root hairs play a key role in the endophytic colonization of olive roots by Pseudomonas spp. with biocontrol activity. Microb Ecol. 2011; 62:435-45. 
7. Schilirò E, Ferrara M, Nigro F, Mercado-Blanco J. Genetic responses induced in olive roots upon colonization by the biocontrol endophytic bacterium Pseudomonas fluorescens PICF7. PLOS ONE. 2012; 7:e48646.

8. Gómez-Lama Cabanás C, Schilirò E, Valverde-Corredor A, Mercado-Blanco J. The biocontrol endophytic bacterium Pseudomonas fluorescens PICF7 induces systemic defense responses in aerial tissues upon colonization of olive roots. Front Microbiol. 2014; 5:427.

9. Maldonado-González MM, Prieto P, Ramos C, Mercado-Blanco J. From the root to the stem, interaction between the biocontrol root endophyte Pseudomonas fluorescens PICF7 and the pathogen Pseudomonas savastanoi NCPPB 3335 in olive knots. Microb Biotechnol. 2013; 6:275-87.

10. Ramos C, Matas IM, Bardaji L, Aragón IM, Murillo J. Pseudomonas savastanoi pv. savastanoi: some like it knot. Mol Plant Pathol. 2012; 13:998-1009.

11. King EO, Ward M, Raney D. Two simple media for the demonstration of pyocyanin and fluorescin. J Lab Clin Med. 1954; 44:301-7.

12. Bertani G. Studies on lysogenesis. I. The mode of phage liberation by lysogenic. J Bacteriol. 1951; 62:293-300.

13. Meyer JM, Abdallah MA. The fluorescent pigment of Pseudomonas fluorescens: biosynthesis, purification and physicochemical properties. J Gen Microbiol. 1978; 107:319-28.

14. Field D, Garrity G, Gray T, Morrison N, Selengut J, Sterk P, Tatusova T, Thomson N, Allen MJ, Angiuoli SV, Ashburner M, Axelrod N, Baldauf S, Ballard S, Boore J, Cochrane G, Cole J, Dawyndt P, Vos PD, dePamphilis C, Edwards R, Faruque N, Feldman R, Gilbert J, Gilna P, Glöckner FO, Goldstein P, Guralnick R, Haft D, Hancock D, et al: The minimum information about a genome sequence (MIGS) specification. Nat Biotechnol. 2008; 26:541-7.

15. Woese CR. Towards a natural system of organisms: Proposal for the domains Archea, Bacteria and Eucarya. Proc Natl Acad Sci USA. 1990; 87:4576-9.

16. Garrity GM, Bell JA, Phylum LT, XIV. phyl. nov. In: Garrity GM, Brenner DJ, Krieg NR, Staley JT, editors. Bergey's Manual of Systematic Bacteriol-ogy, Volume 2. 2nd ed. Springer, New York: Part B; 2005: p. 1.

17. Validation of publication of new names and new combinations previously effectively published outside the IJSEM. List no. 106. Int J Syst Evol Microbiol. 2005; 55:2235-8. http://dx.doi.org/10.1099/ijs.0.64108-0.

18. Garrity GM, Bell JA, Class LT, III. class. nov. In: Garrity GM, Brenner DJ, Krieg NR, Staley JT, editors. Bergey's Manual of Systematic Bacteriology, Volume 2. 2nd ed. Springer, New York: Part B; 2005: p. 1.

19. Skerman VBD, McGowan V, Sneath PHA. Approved lists of bacterial names. Int J Syst Bacteriol. 1980; 30:225-420. http://dx.doi.org/10.1099/00207713-30-1-225.

20. Orla-Jensen $\mathrm{S}$. The main lines of the natural bacterial system. J Bacteriol. 1921: 6:263-73.

21. Garrity G, Bell J, Lilburn T. In: Garrity G, Brenner D, Krieg N, Staley J, editors. Bergey's Manual of Systematic Bacteriology, Volume 2, Part B. 2nd ed. New York: Springer; 2005: p. 323.

22. Winslow CEA, Broadhurst J, Buchanan RE, Krumwiede C, Rogers LA, Smith $\mathrm{GH}$. The fami-lies and genera of the bacteria. Preliminary report of the committee of the society of American Bacteriologists on characterization and classification of bacterial types. J Bacteriol. 1917; 2:505-66.

23. Migula W. Über ein neues System der Bakterien. Arb Bakteriol Inst Karlsruhe. 1894; 1:235-8.

24. Doudoroff M, Palleroni NJ. Genus Migula 1894, 237; Nom. cons. Opin. 5, Jud. Comm. 1952, 121. In: Buchanan RE, Gibbons NE, editors. Bergey's Manual of Determinative Bacteriology. 8th ed. Baltimore: The Williams and Wilkins Co.; 1974: p. 217-43.

25. Commission J. Opinion 5: Conservation of the generic name Migula 1894 and designation of aeruginosa (Schroeter) Migula 1900 as type species. Int Bull Bacteriol Nomend Taxon. 1952; 2:121-2.

26. Palleroni NJ. Pseudomonadaceae. Bergey's Manual of Systematic Bacteriology. In: Krieg NR, Holt JG, editors. Baltimore: The Williams and Wilkins Co; 1984: p. 141-99.

27. Anzai Y, Kim H, Park JY, Wakabayashi H, Oyaizu H. Phylogenetic affiliation of the pseudomonads based on 16S rRNA sequence. Intl J Sys Evol Microbiol. 2000; 50:1563-89

28. Ashburner M, Ball CA, Blake JA, Botstein D, Butler H, Cherry JM, Davis AP, Dolinski K, Dwight SS, Eppig JT, Harris MA, Hill DP, Issel-Tarver L, Kasarskis A, Lewis S, Matese JC, Richardson JE, Ringwald M, Rubin GM, Sherlock G: Gene Ontology: tool for the unification of biology. Nat Genet. 2000; 25:25-9.

29. Jones DT, Taylor WR, Thornton JM. The rapid generation of mutation data matrices from protein sequences. Comput Appl Biosci. 1992; 8:275-82.
30. Felsenstein J. Confidence limits on phylogenies - an approach using the bootstrap. Evolution. 1985; 39:783-91.

31. Liolios K, Mavromatis K, Tavernarakis N, Kyrpides NC. The Genomes On Line Database (GOLD) in 2007: status of genomic and metagenomic projects and their associated metadata. Nucleic Acids Res. 2008; 36:D475-9.

32. Li R, Zhu H, Ruan J, Qian W, Fang X, Shi Z, Li Y, Li S, Shan G, Kristiansen K, Li $\mathrm{S}$, Yang $\mathrm{H}$, Wang J, Wang J: De novo assembly of human genomes with massively parallel short read sequencing. Genome Res. 2010; 20:265-72.

33. Li R, Li Y, Kristiansen K, Wang J. SOAP: short oligonucleotide alignment program. Bioinformatics. 2008; 24:713.

34. SOAP. denovo v.1.05. http://soap.genomics.org.cn/soapdenovo.html.

35. Signal P. http://www.cbs.dtu.dk/services/SignalP/.

36. Emanuelsson $\mathrm{O}$, Brunak $\mathrm{S}$, von Heijne $\mathrm{G}$, Nielsen $\mathrm{H}$. Locating proteins in the cell using TargetP, SignalP and related tools. Nat Protoc. 2007; 2:953-71.

37. Krogh A, Larsson B, von Heijne G, Sonnhammer EL. Predicting transmembrane protein topology with a hidden Markov model: application to complete genomes. J Mol Biol. 2001; 305:567-80.

38. TMHMM. Transmembrane domain prediction. www.cbs.dtu.dk/services/TMHMM/.

39. Tatusov RL, Koonin EV, Lipman DJ. A genomic perspective on protein families. Science. 1997; 278:631-7.

40. Clusters of Ortholog ous Groups. http://www.ncbi.n/m.nih.gov/COG.

41. Hood RD, Singh P, Hsu F, Güvener T, Carl MA, Trinidad RR, Silverman JM, Ohlson BB, Hicks KG, Plemel RL, Li M, Schwarz S, Wang WY, Merz AJ, Goodlett DR, Mougous JD: A type VI secretion system of Pseudomonas aeruginosa targets a toxin to bacteria. Cell Host Microbe. 2010; 7:25-37.

42. Matthysse $A G$, Jaeckel $P$, Jeter $C$. att $G$ and attC mutations of Agrobacterium tumefaciens are dominant negative mutations that block attachment and virulence. Can J Microbiol. 2008; 54:241-7.

43. Colburn-Clifford JM, Scherf JM, Allen C. Ralstonia solanacearum Dps contributes to oxidative stress tolerance and to colonization of and virulence on tomato plants. Appl Environ Microbiol. 2010; 76:7392-9.

44. Guo M, Block A, Bryan CD, Becker DF, Alfano JR. Pseudomonas syringae Catalases Are Collectively Required for Plant Pathogenesis. J Bacteriol. 2012; 194:5054-64

45. Sudo T, Shinohara K, Dohmae N, Takio K, Usami R, Horikoshi K, Osada H. Isolation and characterization of the gene encoding an aminopeptidase involved in the selective toxicity of ascamycin toward Xanthomonas campestris pv. citri. Biochem J. 1996; 319(Pt 1):99-102.

46. Peñaloza-Vázquez A, Kidambi SP, Chakrabarty AM, Bender CL. Characterization of the alginate biosynthetic gene cluster in Pseudomonas syringae pv. syringae. J Bacteriol. 1997; 179:4464-72.

47. Ren Y, Strobel G, Sears J, Park M. Geobacillus sp., a thermophilic soil bacterium producing volatile antibiotics. Microb Ecol. 2010; 60:130-6

48. Ryu CM, Farag MA, Hu CH, Reddy MS, Wei HX, Paré PW, Kloepper JW. Bacterial volatiles promote growth in Arabidopsis. Proc Natl Acad Sci U S A 2003; 100:4927-32

49. Ahmad F, Ahmad I, Khan MS. Screening of free-living rhizospheric bacteria for their multiple plant growth promoting activities. Microbiol Res. 2008; 163:173-81.

50. Hardoim PR, van Overbeek LS, van Elsas JD. Properties of bacterial endophytes and their proposed role in plant growth. Trends Microbiol. 2008; 16:463-71.

doi:10.1186/1944-3277-10-10

Cite this article as: Martínez-García et al:: Complete genome sequence of Pseudomonas fluorescens strain PICF7, an indigenous root endophyte from olive (Olea europaea L.) and effective biocontrol agent against Verticillium dahliae. Standards in Genomic Sciences 2015 10:10. 